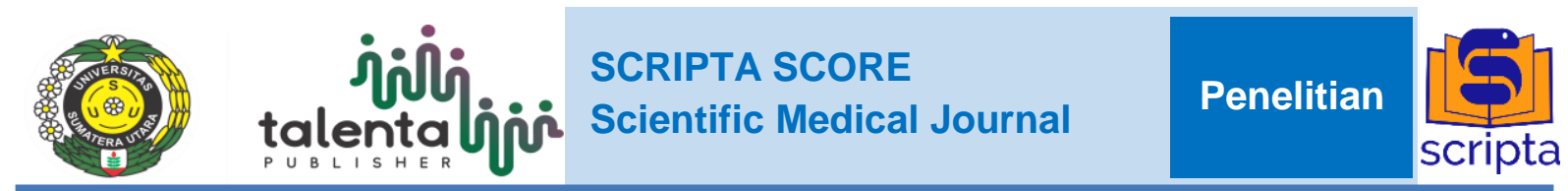

\section{Hubungan Kualitas Tidur dan Fungsi Kognitif Siswa MAN Binjai}

\author{
Said Fachlefi*, Aldy Safruddin Rambe \\ Departemen Neurologi, Fakultas Kedokteran, Universitas Sumatera Utara, Medan \\ *Correspondence: fachlefisaid@gmail.com
}

\begin{abstract}
ABSTRAK
Latar Belakang: Tidur merupakan kebutuhan pokok manusia. Tidur diperlukan otak untuk melaksanakan penyesuaian-penyesuaian kimiawi dan struktural jangka panjang yang diperlukan untuk belajar dan mengingat. Kemajuan teknologi yang begitu pesat belakangan ini dapat mengurangi durasi tidur terutama pada remaja. Kualitas tidur yang buruk dapat memengaruhi fungsi kognitif yang akan berpengaruh terhadap proses belajar siswa. Tujuan: Secara umum penelitian ini bertujuan untuk mengetahui hubungan kualitas tidur dengan fungsi kognitif siswa MAN Binjai. Metode: Penelitian ini merupakan penelitian dengan metode analitik dengan desain penelitian potong lintang. Pengambilan data dilakukan hanya sekali untuk mengumpulkan data primer dengan alat ukur berupa kuesioner MoCA dan PSQI. Teknik stratified random sampling digunakan untuk menentukan jumlah sampel. Sampel berjumlah 60 orang. Korelasi spearman digunakan dalam analisis data. Hasil: Dari studi didapatkan $r=-0.76(\mathrm{p}<0.05)$ yang menunjukkan adanya korelasi sedang dan berbanding terbalik antara kuesioner M0CA dan PSQI. Kesimpulan: Terdapat hubungan antara kualitas tidur dengan fungsi kognitif pada siswa MAN Binjai.
\end{abstract}

Kata Kunci: fungsi kognitif, kualitas tidur, MoCA, PSQI, siswa

\section{ABSTRACT}

Background: Sleep is a basic requirement of human beings. Sleeping brain is required to carry out adaptations to long-term structural and chemical needed to learn and remember. Rapid technological advances in recent times can reduce the duration of sleep especially in teenagers. A bad quality of sleep may affect cognitive function that will have an effect on students learning process. Objectives: In general, this research aims to know the relationship between sleep quality with cognitive function of MAN Binjai student. Methods: This research is a study of analytical method with cross sectional design. Data retrieval is performed only once for collecting primary data with the measuring instrument in the form of a questionnaire. Stratified random sampling technique was used to determine the number of samples. Results: on the analysis of correlation Sprearman obtained a value of $0.001 P(p<0.05)$ indicating there is a relationship between sleep quality and cognitive function. The correlation coefficient $(r)$ is -0.764 , which indicates medium relationship between sleep quality and cognitive function of MAN Binjai student. Conclusion: There is a relationship that is directly proportional between the sleep quality with cognitive function in MAN Binjai students.

Keywords: cognitive function, MoCA, PSQI, sleep quality, student Received [10 Jan 2021] | Revised [7 May 2021] | Accepted [25 Jun 2021]

PENDAHULUAN
Tidur merupakan kebutuhan
pokok manusia dan diperlukan oleh
otak untuk melaksanakan penyesuaian-

penyesuaian kimiawi dan struktural jangka panjang yang diperlukan untuk belajar dan mengingat. ${ }^{[1]}$ Tidur yang berkualitas merupakan akumulasi 
penilaian dari beberapa komponen sep erti durasi tidur, latensi tidur, kualitas tidur subjektif, efisiensi, gangguan tidur, serta ada tidaknya penggunaan obat sebelum tidur. ${ }^{[2]}$

Hasil penelitian Centers for Disease Control and Prevention pada tahun 2014 menunjukkan 35,2 \% orang dewasa muda di Amerika Serikat memiliki kualitas tidur yang buruk. ${ }^{[3]}$ Penelitian yang dilakukan di Jakarta dengan sampel remaja ditemukan prevalensi gangguan tidur sebesar $62,9 \%{ }^{[4]}$

Maraknya penggunaan teknologi belakangan ini, seperti penggunaan internet dan sosial media dapat menyebabkan menurunnya kualitas tidur terutama pada. ${ }^{[5]}$ Kualitas tidur akan berpengaruh pada fungsi kognitif seseorang, dimana pada saat tidur terjadi peningkatan aliran darah ke otak, peningkatan konsumsi oksigen, yang dapat membantu penyimpanan memori dan pembelajaran yang berhubungan dengan fungsi kognitif seseorang. ${ }^{[6]}$ Penelitian pada orang dewasa muda sehat menunjukkan bahwa deprivasi tidur menyebabkan perubahan pada neurofisiologi dan kinerja endokrin yang ditandai dengan gangguan fungsi kognitif. ${ }^{[7]}$

Kualitas tidur yang baik sangat penting untuk pelajar. Adapun akibat dari pe nurunan kualitas tidur yang berkaitan dengan fungsi kognitif, yaitu akan mengakibatkan terjadinya kesulitan dalam proses belajar, pengambilan keputusan, memecahkan masalah, menerima memori baru yang akan berdampak pada prestasi belajar siswa tersebut di sekolah. ${ }^{[8]}$ Sebuah penelitian yang dilakukan pada mahasiswa Walden University, Newyork City tahun 2015 menunjukkan terdapat hubungan antara kualitas tidur dengan memori jangka pendek. ${ }^{[9]}$

Terdapat beberapa penelitian yang menghubungkan kualitas tidur dengan fungsi kognitif seseorang. Penelitian pada lansia di provinsi Sulawesi Utara menunjukkan terdapat hubungan yang signifikan antara kualitas tidur dengan fungsi kognitif. ${ }^{[10]}$ Penelitian dengan hasil yang sama juga dilakukan pada pasien dengan penyakit Parkinson dan pada bidan $^{[11,12]}$. Untuk itu penelitian ini ditujukan untuk melihat hubungan kualitas tidur dengan fungsi kognitif pada remaja khususnya siswa - siswi di sekolah Madrasah Aliyah Negeri Binjai.

\section{METODE}

Dalam penelitian ini, yang menjadi populasi adalah siswa-siswi MAN Binjai. Jumlah populasi penelitian yaitu jumlah seluruh siswa-siswi MAN Binjai.

Teknik pengambilan sampel pada penelitian ini adalah stratified random sampling. Sampel diambil berdasarkan pertimbangan tertentu yang dibuat oleh peneliti, berdasarkan ciri atau sifat populasi yang sudah ditetapkan sebelumnya. ${ }^{[13]}$ Setiap responden yang memenuhi kriteria penelitian akan dimasukkan dalam sebagai sampel hingga jumlah sampel yang diperlukan terpenuhi. ${ }^{[14]}$ Sampel dari penelitian ini adalah siswa MAN Binjai kelas X, XI, dan XII yang memenuhi kriteria inklusi dan eksklusi. Perkiraan besar sampel pada penelitian ini ditentukan dengan menggunakan rumus besar sampel penelitian untuk koefisien korelasi dengan sampel tunggal :

$$
\begin{gathered}
\mathrm{n}=\left[\frac{z a+z \beta}{0.5 \operatorname{In}[(1+r) /(1-r)]}\right]^{2}+3 \\
\mathrm{n}=\left[\frac{1,645+0,842}{0.5 \operatorname{In}[(1-0,330) /(1+0,330)]}\right]^{2}+3 \\
\mathrm{n}=[53,29]+3 \\
\mathrm{n}=56,29 \\
\text { Keterangan : } \\
\mathrm{n}=\text { besar sampel minimum } \\
\mathrm{z} \alpha=\text { kesalahan tipe I, } \alpha \\
\mathrm{z} \beta=\text { kesalahan tipe II, } \beta \\
\mathrm{r}=\text { Perkiraan koefisien korelasi (dari }
\end{gathered}
$$

penelitian sebelumnya) 
Peneliti menggunakan derajat kesalahan alpha sebesar 5\%, sehingga didapatkan nilai $z \alpha=1,645$; Peneliti mengambil derajat kesalahan beta sebesar $20 \%$, sehingga didapatkan nilai $z \beta=$ 0,$842 ; \quad r=-0,330$. Nilai $r$ sebesar $-0,330$ dikarenakan peneliti menemukan pada penelitian sebelumnya hubungam kualitas tidur dengan komponen kognitif sebesar $0,330 .^{[15]}$

Jumlah sampel dibulatkan menjadi 59 oleh peneliti. Peneliti membagi total sampel menjadi 3 kelompok besar berdasarkan tingkatan kelas yaitu 20 sampel dari tingkatan kelas I, 19 sampel dari stingkatan kelas II, dan 20 sampel dari tingkatan kelas XII.

Sampel dipilih dengan menggunakan kriteria inklusi dan eksklusi sebagai berikut:

1. Kriteria Inklusi:

a. Siswa MAN Binjai tahun 2018.

b. Bersedia menjadi sampel dan menyelesaikan penelitian

c. Tidak ada riwayat atau terdiagnosis gangguan neurologis atau psikiatri yang mempengaruhi fungsi kognitif.

2. Kriteria Eksklusi:

Tidak terdapat kriteria eksklusi.

Pada penelitian ini instrumen penelititan yang digunakan antara lain; Kuesioner Pittsburgh Sleep Quality Index (PSQI) dan kuesioner Montreal Cognitive Assesment (MoCA) yang telah diterjemahkan ke Bahasa Indonesia.

Pittsburgh Sleep Quality Index (PSQI) merupakan salah satu instrumen pengukuran kualitas tidur yang telah banyak dipakai. Pittsburgh Sleep Quality Index (PSQI) terdiri dari 19 pertanyaan yang dijawab sendiri dan 5 pertanyaan yang dijawab oleh teman sekamar. Hanya pertanyaan yang dijawab sendiri yang digunakan dalam penilaian, sedangkan pertanyaan yang dijawab teman sekamar hanya untuk informasi klinis. ${ }^{[2]}$ Jumlah pertanyaan yang digunakan dalam penilaian adalah 18 pertanyaan. Penilaian terhadap 18 pertanyaan yang dijawab sendiri menghasilkan 7 nilai komponen terhadap kualitas tidur. Skor setiap komponen memiliki rentang dari 0 sampai 3. Tiap komponen dijumlahkan untuk menilai skor total. Nilai kualitas tidur yang baik apabila total skor $\leq 5$. Sedangkan nilai kualitas tidur yang buruk apabila total skor $>5 .^{[2]}$

Kuesioner MoCA merupakan kuesioner yang sensitif dan lengkap dalam menilai fungsi kognitif seseorang. ${ }^{[17]}$ Pada penelitian lain ditemukan Sensitivitas MMSE dalam skrining gangguan kognitif ringan (Mild Cognitive Impairment) berada di bawah alat pengukuran Montreal Cognitive Assesstment (MoCA). ${ }^{[16]}$ Oleh karena itu dalam penelitian ini, peneliti menggunakan kuesioner MoCA karena merupakan kuesioner yang sensitif dan lengkap dalam menilai fungsi kognitif seseorang. Kuesioner ini telah diuji validitas dan reliabilitas di indonesia. ${ }^{[18]}$

\section{HASIL}

Data yang digunakan diambil dari responden yang telah menyelesaikan rangkaian penelitian dari awal hingga akhir sebanyak 59 responden penelitian, yang terdiri dari 22 responden laki-laki dan 37 responden perempuan yang memenuhi kriteria penelitian. Dari penelitian di dapatkan rata-rata umur sampel adalah 15,42 dengan standar deviasi sebesar 0,969. Karakteristik demografi lengkap dari responden dapat dilihat di Tabel 4.1. 
Tabel 4.1 Karakteristik Demografi Responden

\begin{tabular}{lcc}
\hline & $\mathbf{n = 5 9}$ & $\mathbf{( \% )}$ \\
\hline Umur & & \\
14 tahun & 11 & $(18,6)$ \\
15 tahun & 21 & $(35,6)$ \\
16 tahun & 18 & $(30,5)$ \\
17 tahun & 9 & $(15,3)$ \\
Jenis & & \\
kelamin & & \\
$\quad$ Laki-laki & 22 & $(37,3)$ \\
$\quad$ Perempuan & 37 & $(62,7)$ \\
Distribusi & & \\
kelas & & \\
$\quad$ Kelas 1 & 20 & $(33,9)$ \\
Kelas 2 & 19 & $(32,3)$ \\
Kelas 3 & 20 & $(33,9)$ \\
\hline
\end{tabular}

Pengamatan dilakukan dengan wawancara terpimpin satu per satu untuk mengisi kuesioner PSQI dan Moca. Pada pengamatan didapatkan distribusi variabel penelitian seperti pada Tabel 4.2.

Tabel 4.2. Distribusi Variabel Penelitian Secara Keseluruhan

\begin{tabular}{ccccc}
\hline Variabel & $\begin{array}{c}\text { Mean } \pm \\
\text { SD }\end{array}$ & Range & Baik & Buruk \\
& & & \\
\hline PSQI & $6,53 \pm$ & $0-21$ & 21 & 38 \\
& 2,615 & & $(35,6 \%)$ & $(64,4 \%)$ \\
MoCA & $25,80 \pm$ & $0-30$ & 34 & 25 \\
& 1,928 & & $(57,6 \%)$ & $(42,4 \%)$ \\
\hline
\end{tabular}

Berdasarkan Tabel 4.2 diatas, didapatkan nilai rata-rata, standar deviasi, range, jumlah skor yang dikategorikan baik dan buruk pada kuesioner PSQI dan MoCA pada responden. Nilai rata-rata PSQI responden adalah sebesar 6,53 dengan standar deviasi 2,615. Jumlah siswa dengan kualitas tidur yang baik sesuai dengan kuesioner PSQI sebesar 35,6\% dan kualitas tidur yang buruk sesuai kuesioner PSQI sebesar $64,4 \%$. Kualitas tidur yang baik ditandai dengan skor komponen PSQI yang rendah. Nilai kualitas tidur yang baik apabila total skor $\leq 5$, Sedangkan nilai kualitas tidur yang buruk apabila total skor $>5 .^{[2]}$
Nilai rata-rata MoCA responden adalah sebesar 25,80 dengan standar deviasi 1,928. Jumlah siswa dengan fungsi kognitif yang baik sesuai kuesioner MoCA sebesar $57,6 \%$ dan fungsi kognitif yang buruk sesuai dengan kuesioner MoCA sebesar 42,4\%.Nilai MoCA dianggap baik apabila skor $\geq 26$, Nilai kuesioner MoCA < 26 dianggap kurang baik untuk fungsi kognitif seseorang. ${ }^{[17]}$

Distribusi nilai setiap komponen PSQI dapat dilihat pada Tabel 4.3

Tabel 4.3 Distribusi Setiap Komponen PSQI

\begin{tabular}{lcc}
\hline \multicolumn{1}{c}{ Variabel } & Mean \pm SD & Range \\
\hline PSQI & & \\
Subjektif & $1,20 \pm 0,783$ & $0-3$ \\
Latensi & $1,22 \pm 0,832$ & $0-3$ \\
Durasi & $1,17 \pm 0,894$ & $0-3$ \\
Efisiensi & $0,19 \pm 0,508$ & $0-3$ \\
Gangguan & $1,34 \pm 0,512$ & $0-3$ \\
Obat & $0,24 \pm 0,625$ & $0-3$ \\
Disfungsi & $1,14 \pm 0,819$ & $0-3$ \\
\hline
\end{tabular}

Tabel 4.3 menunjukkan distribusi nilai masing-masing komponen PSQI. Komponen subjektif didapatkan nilai ratarata pada responden sebesar 1,20 dengan standar deviasi sebesar 0,783 dan nilai maksimum dan minimum masing-masing sebesar 3 dan 0. Rata-rata untuk komponen latensi sebesar 1,22 dengan standar deviasi 0,832 , dan nilai maksimum dan minimum masing-masing sebesar 3 dan 0. Rata-rata nilai untuk komponen durasi adalah 1,17 dengan standar deviasi sebesar 0,894, dan nilai maksimum dan minimum masingmasing sebesar 3 dan 0 . Rata-rata nilai untuk komponen efisiensi adalah 0,19 dengan standar deviasi 0,508 , serta nilai maksimum dan minimum masing-masing adalah 3 dan 0 .

Rata-rata nilai untuk komponen gangguan adalah 1,33 dengan standar deviasi sebesar 0,512 , serta nilai maksimum dan minimum masing-masing sebesar 3 dan 0. Rata-rata nilai untuk 
komponen obat adalah 0,24 dengan standar deviasi sebesar 0,625 dengan nilai maksimum dan minimum masing-masing sebesar 3 dan 0. Rata-rata nilai untuk komponen disfungsi adalah 1,14 dengan standar deviasi sebesar 0,819 dengan nilai maksimum dan minimum masing-masing sebesar 3 dan 0.

Distribusi nilai setiap komponen MoCA dapat dilihat pada Tabel 4.4

Tabel 4.4 Distribusi Setiap Komponen MoCA

\begin{tabular}{lcc}
\hline \multicolumn{1}{c}{ Variabel } & Mean \pm SD & Range \\
\hline MoCA & & \\
Visuospasial & $4,51 \pm 0,728$ & $0-5$ \\
Penamaan & $2,98 \pm 0,130$ & $0-3$ \\
Atensi & $5,37 \pm 0,927$ & $0-6$ \\
Bahasa & $1,92 \pm 0,596$ & $0-3$ \\
Abstraksi & $0,90 \pm 0,803$ & $0-2$ \\
Delayed & $4,15 \pm 1,014$ & $0-5$ \\
recall & & \\
$\quad$ Orientasi & $5,97 \pm 0,183$ & $0-6$ \\
\hline
\end{tabular}

Tabel 4.4 menunjukkan distribusi nilai masing-masing komponen MoCA. Komponen visuospasial didapatkan nilai rata-rata pada responden sebesar 4,51 dengan standar deviasi sebesar 0,728 dan nilai maksimum dan minimum pada komponen ini masing-masing sebesar 5 dan 0. Rata-rata nilai untuk komponen penamaan adalah 2,98 dengan standar deviasi 0,130 dan nilai maksimum dan minimum pada komponen ini masingmasing sebesar 3 dan 0 .

Rata-rata nilai untuk komponen atensi adalah 5,37 dengan standar deviasi 0,927 dan nilai maksimum dan minimum pada komponen ini masing-masing sebesar 6 dan 0. Rata-rata nilai untuk komponen bahasa adalah 1,92 dengan standar deviasi 0,596 dan nilai maksimum dan minimum pada komponen ini masing-masing sebesar 3 dan 0. Rata-rata nilai untuk komponen abstraksi adalah 0,90 dengan standar deviasi 0,803 dan nilai maksimum dan minimum pada komponen ini masingmasing sebesar 2 dan 0 .
Rata-rata nilai untuk komponen delayed recall adalah 4,15 dengan standar deviasi 1,014 dan nilai maksimum dan minimum pada komponen ini masing-masing sebesar 5 dan 0. Rata-rata nilai untuk komponen orientasi adalah 5,97 dengan standar deviasi 0,183 dan nilai maksimum dan minimum pada komponen ini masingmasing sebesar 6 dan 0 .

Analisis hubungan kualitas tidur dengan fungsi kognitif pada penelitian ini diawali dengan uji normalitas terlebih dahulu untuk menentukan uji korelasi yang digunakan. Uji korelasi Pearson digunakan apabila sampel terdistribusi normal dan uji korelasi Spearman apabila sampel tidak terdistribusi normal. ${ }^{[4]}$

Tabel 4.5 Analisis Normalitas

\begin{tabular}{cc}
\hline Variabel & P Value \\
\hline PSQI & 0,001 \\
MoCA & 0,001 \\
\hline
\end{tabular}

Tabel 4.5 menunjukkan bahwa dari hasil uji normalitas, pada variabel PSQI diperoleh Nilai P sebesar $0,001(<0,05)$ dan Moca sebesar $0,001 \quad(<0,05)$ yang berarti data tidak terdistribusi normal, sehingga uji korelasi yang digunakan pada penelitian ini adalah uji korelasi Spearman.

Tabel 4.6 menunjukkan bahwa dari uji korelasi didapatkan Nilai P sebesar 0,001 $(<0,05)$ yang berarti ada hubungan antara kualitas tidur dengan fungsi kognitif siswa MAN Binjai. Koefisien korelasi didapatkan sebesar -0,764. Koefisien korelasi menunjukkan hasil negatif, yang berarti bahwa hasil berbanding terbalik (Semakin tinggi nilai PSQI maka semakin rendah nilai MoCA). 
Tabel 4.6 Analisis Korelasi Kualitas Tidur dan Fungsi Kognitif

\begin{tabular}{lllcc}
\hline & & & PSQI & MoCA \\
\hline Uji & PSQI & Koefisien & & $-0,764$ \\
korelasi & & korelasi & & \\
spearman & & P Value & & 0,001 \\
& & total & 59 & 59 \\
\cline { 2 - 4 } & MoCA & Koefisien & - & \\
& & korelasi & 0.764 & \\
& & 0,001 & \\
& & & 59 & 59 \\
\hline
\end{tabular}

Semakin tinggi nilai PSQI menunjukkan semakin buruk kualitas tidur seseorang, sementara semakin rendah nilai MoCA menunjukkan semakin buruk fungsi kognitif seseorang. Koefisien korelasi tersebut menunjukkan terdapat korelasi sedang antara kualitas tidur dan fungsi kognitif siswa MAN Binjai, dimana korelasi kuat apabila $(r>0,8)$, sedang $(0,6-$ $0,79)$, lemah $(0,4-0,59)$, sangat lemah $(<0,4)$.

\section{PEMBAHASAN}

Berdasarkan hasil kuesioner PSQI, terdapat hasil yang bervariasi pada kualitas tidur siswa MAN Binjai. Kualitas tidur yang baik pada siswa MAN Binjai dikarenakan normal nya durasi tidur,durasi tidur yang sesuai dengan usia mereka, minimnya gangguan tidur yang mereka rasakan, permulaan tidur yang baik, serta minimnya penggunaaan obat tidur oleh mereka sebelum mereka tidur. ${ }^{[2]}$

Kualitas tidur yang buruk dapat dipengaruhi oleh berbagai hal diantaranya maraknya penggunaan internet yang dikarenakan kemajuan teknologi begitu pesat belakangan ini menjadi salah satu penyebab berkurangnya durasi tidur terutama pada remaja. Disamping itu aktifitas sosial yang padat pada siswa baik berhubungan dengan aktifitas sosial media ataupun yang berhubungan dengan kegiatan akademik siswa tersebut, seperti keharusan untuk mengakses internet untuk mencari tugas sekolah, hal ini akan mempengaruhi pola tidur pada remaja. ${ }^{[19]}$ Aktivitas-aktivitas tersebut akan manghasilkan kurangnya durasi tidur pada siswa, tertundanya waktu tidur pada siswa tersebut. Perbedaan pola tidur pada hari kerja dan akhir pekan juga menyebabkan kualitas tidur remaja menjadi cenderung berkurang. Hal ini sesuai dengan penelitian yang dilakukan di Jakarta dengan sampel remaja usia 12-15 tahun dimana ditemukan prevalensi gangguan tidur sebesar 62,9\%. ${ }^{[4]}$ Perubahan gaya hidup, peningkatan penggunaan teknologi seperti penggunaan sosial media, peningkatan beban pekerjaan, dan kebutuhan sosial juga merupakan penyebab penurunan kualitas tidur pada usia dewasa muda. ${ }^{[5]}$

Metode pengumpulan data dengan menggunakan kuesioner juga dapat memengaruhi hasil penelitian tersebut. Metode penelitian berupa kuesioner dilakukan dengan memberi beberapa daftar pertanyaan kepada responden. Terdapat beberapa kelemahan dari metode ini yang dapat memengaruhi hasil penelitian diantaranya adalah adanya kemungkinan bahwa responden menandai begitu saja salah satu pilihan sekadar memenuhi permintaan peneliti kepadanya untuk mengisi kuesioner tersebut tanpa memikirkan benar-benar apakah jawaban itu sesuai atau tidak dengan pendiriannya. Kengganan siswa untuk meluangkan waktu yang banyak untuk mengisi kuesioner tersebut juga menjadi salah satu hal yang dapat meengaruhi kuesioner yang diisi olehnya. ${ }^{[14]}$

Pada hasil kuesioner MoCA juga menunjukkan hasil yang bervariasi pada setiap siswa MAN Binjai. Kuesioner MoCA merupakan kuesioner yang sensitif dan lengkap dalam menilai fungsi kognitif seseorang, Fungsi kognitif yang baik menunjukkan bahwa siswa memiliki atensi, memori, visuospasial, bahasa dan fungsi eksekutif yang baik saat dilakukan pemeriksaan. ${ }^{[17]}$ Siswa yang mendapatkan fungsi kognitif kurang baik dapat dikarenakan kurangnya konsentrasi saat pemeriksaan. Keadaan ini dapat terjadi diakibatkan kurangnya tidur mahasiswa 
pada malam hari sebelum pemeriksaan, kurangnya tidur tersebut akan berakibat ngantuknya siswa pada siang hari, merasa lelah, dan suasana hati yang kurang baik. ${ }^{[20]}$

Hasil ini menyatakan adanya hubungan antara kualitas tidur dan fungsi kognitif seseorang, dimana semakin baik kualitas tidur seseorang maka akan semakin baik fungsi kognitifnya. Hasil ini dapat dijelaskan dengan teori yang ada, diantaranya terdapat perubahan metabolisme pada otak manusia ketika mengalami penurunan kualitas tidur. Diantara penyebabnya adalah terdapat penurunan yang signifikan pada laju metabolisme di lobus frontalis dan temporalis, talamus, ganglia basalis, dan cerebelumsehingga fungsi kognitif akan terganggu. ${ }^{[21]}$

Penelitian pada lansia di provinsi Sulawesi Utara juga menunjukkan terdapat hubungan yang signifikan antara kualitas tidur dengan fungsi kognitif. ${ }^{10}$ Penelitian lain yang dilakukan pada pasien dengan penyakit Parkinson yang mengalami penurunan kualitas tidur juga menunjukkan penurunan fungsi kognitif. ${ }^{[11]}$ Penelitian lain yang berhubungan kualitas tidur dan fungsi kognitif pada bidan dengan kualitas tidur yang buruk, dimana hasilnya sejalan dengan penelitian ini yaitu terdapat penurunan fungsi kognitif pada siswa dengan penurunan kualitas tidur. ${ }^{[12]}$

\section{KESIMPULAN}

Terdapat korelasi sedang antara kualitas tidur dan fungsi kognitif pada siswa MAN Binjai, dimana semakin baik kualitas tidur siswa maka akan semakin baik fungsi kognitifnya dan semakin buruk kualitas tidur siswa maka semakin buruk fungsi kognitifnya.

\section{SARAN}

Berdasarkan penelitian yang telah dilakukan, saran yang dapat disampaikan adalah:

1. Peneliti menyarankan kepada siswa untuk menjaga kualitas tidur sehingga fungsi kognitif nya baik. Fungsi kognitif yang baik akan berdampak positif pada prestasi pelajar di sekolah dan gangguan fungsi kognitif akan berdampak pada gangguan cara berpikir,interaksi sosial atau aktivitas sehari-hari yang akan berdampak negatif pada prestasi belajar siswa tersebut di sekolah.

2. Penelitian lebih lanjut dengan jumlah sampel yang lebih besar serta alat diagnostik yang lebih spesifik diperlukan untuk menghubungkan kualitas tidur dan fungsi kognitif pada siswa.

\section{DAFTAR PUSTAKA}

[1] Sherwood, L. 2015, Fisiologi Manusia dari Sel ke Sistem, EGC, Jakarta

[2] Bush, A. L., Armento, M. E. A., Weiss, B. J., Rhoades, H. M., Novy, D. M., Wilson, N. L., Kunik, M. E. and Stanley, M. A. 2012, 'The Pittsburgh Sleep Quality Index in older primary care patients with generalized anxiety disorder: Psychometrics and outcomes following cognitive behavioral therapy', Psychiatry Research. Elsevier, vol. 199, no. 1, pp. 24-30. doi:

10.1016/j.psychres.2012.03.045

[3] Center for Disease Control and Prevention (CDC). 2014, Data and Statistics - Sleep and Sleep disorder. accessed 22 may 2018, available at: https://www.cdc.gov/sleep/data_sta tistics.html

[4] Haryono, A., Rindiarti, A., Arianti, A., Pawitri, A., Ushuluddin, A., Setiawati, A., Reza, A., Wawolumaja, C. W. and Sekartini, R. 2009, 'The Prevalence of Sleep Disorder among Teenager 12 - 15 
years old in Junior High School', Sari Pediatri, vol. 11, no. 3, pp. 149-154

[5] Lemma, S., Gelaye, B., Berhane, Y., Worku, A. and Williams, M. A. 2012, 'Sleep quality and its psychological correlates among university students in Ethiopia: A cross-sectional study', BMC Psychiatry. BMC Psychiatry, vol. 12, no. 1, p. 1. doi: $10.1186 / 1471-$ 244X-12-237

[6] Potter, P. A., perry, A. G. 2012, Buku ajar fundamental keperawatan: konsep, proses dan praktik, EGC, Jakarta

[7] Klumpers, U. M. H., Veltman, D. J., van Tol, M.-J., Kloet, R. W., Boellaard, R., Lammertsma, A. A. and Hoogendijk, W. J. G. 2015, 'Neurophysiological Effects of Sleep Deprivation in Healthy Adults, a Pilot Study', Plos One, vol. 10, no. 1, p. e0116906. doi: 10.1371/journal.pone.0116906

[8] Harsono. 2011, Neurologi Klinis, Gajah Masa University Press, Yogyakarta

[9] Uddin, A. 2015, 'Effect of Sleep on Vigilance, Short-Term Memory, and Learning in College Students', ProQuest Dissertations and Theses, p. 134.

[10] Sari, R. I., Onibala, F., Sumarauw, L.2017, 'Hubungan Kualitas Tidur dengan Fungsi Kognitif Pada Lansia di BPLU Senja Cerah Provinsi Sulawesi Utara', e-journal Keperawatan, vol. 5, no. 1

[11] Liu, H. M., Chu, M., Li, N., Zhang, S., Zhang, Y. Z. and Gu, P. 2018, 'Relationship between Sleep Quality and Cognitive Function in Patients with Mild - to - Moderate Parkinson 's Disease', vol. 131, no. 8, pp. 994-997. doi: 10.4103/0366$\underline{6999.229908}$

[12] Kaliyaperumal, D., Elango, Y., Alagesa, M., Santhanakrishanan, I. 2017, 'Effects of Sleep Deprivation on the Cognitive Performance of Nurses Working in Shift', Journal of Clinical and Diagnostic Research, vol. 11, no.8

[13] Notoatmodjo, S. 2012, Promosi Kesehatan dan Prilaku Kesehatan. Rineka cipta, Jakarta

[14] Dahlan, M. S. 2013, Besar Sampel dan Cara Pengambilan Sampel dalam Penelitian Kedokteran dan Kesehatan, Salemba Medika, Jakarta

[15] Russo, M., Mahon, K., Shanahan, M., Ramjas, E., Solon, C., Purcell, S. M. and Burdick, K. E. 2015, 'The Relationship between Sleep Quality and Neurocognition in Bipolar Disorder HHS Public Access', J Affect Disord November, vol. 15, no. 187, pp. 156-162. doi: 10.1016/j.jad.2015.08.009

[16] Pendlebury, S. T., Mariz, J., Bull, L., Mehta, Z., Rothwell, P. M. and FMedSci, F. 2012, 'MoCA, ACE-R and MMSE versus the NINDSCSN VCI Harmonisation Standards Neuropsychological Battery after TIA and stroke Europe PMC Funders Group', Stroke, vol. 43, no. 2, pp. 464-469. doi:

$\underline{\text { 10.1161/STROKEAHA.111.63358 }}$ $\underline{6}$

[17] Nasreddin, ZS., Phillips, NA., Bedirian, V., Charbonneau, S., Whitehead, V. and Collin, I., Cummings, JL., Chertkow, H. 2005, 'The Montreal Cognitive Assessment, MoCA : A Brief Screening', pp. 695-699

[18] Rambe, A. S. and Fitri, F. I. 2017, 'Correlation between the Montreal Cognitive Assessment- Indonesian Version ( Moca-INA) and the Mini-Mental State Examination ( MMSE ) in Elderly', J Med Sci, vol. 5, no. 7, pp. 915-919

[19] Diarti, E., Sutriningsih, A., Rahayu, W. 2016, 'Hubungan Antara Penggunaan Internet 
dengan Gangguan Pola Tidur pada Mahasiswa PSIK UNITRI Malang', Nursing News, vol. 1, no. 2, pp. 1

[20] Eliasson, A. H. and Lettieri, C. J. 2010, 'Early to bed, early to rise ! Sleep habits and academic performance in college students', pp. 71-75. doi: 10.1007/s11325009-0282-2

[21] Goel, N., Rao, H., Durmer, J. S., Dinges, D. F. 2009, 'Neurocognitive Consequences of Sleep Deprivation'. Semin Neurol, vol. 29, no. 4, pp. 320-339. doi:

$\underline{10.1055 / \mathrm{s}-0029-1237117}$ 